\title{
Comparative analysis of candidate vaccines to prevent covid 19 pandemic
}

\author{
Radha Yadav $^{1}$ and Lalita Chopra ${ }^{2 *}$ \\ ${ }^{1}$ University Institute of Sciences (UIS), Department of chemistry, Chandigarh University, Gharuan, Mohali, Punjab and 140413, India
}

\begin{abstract}
Covid-19 which is a SARS-CoV-2 (severe acute respiratory syndrome) has caused the new overall pandemic moreover is an arising virus profoundly contagious namely coronavirus. The unavailability of a particular antiviral treatment had led to the utmost destruction of life because of this virus. During this time, impressive efforts were placed into creating safe medications and immunizations against SARS-CoV-2. Just 56 vaccines made it at the different clinical stages from more than 80 clinical trials which had started including 23 antibody candidates got looked at moreover had affirmed for the use. Various types of variables are utilized for the production of such vaccines to start the immune reaction to produce antibodies in a person for killing the virus. The countries which are top of the race for producing vaccines are Russia, India, U.S.A., China as well U.K. Among the vaccines produced by these countries are Covaxin (India), Sputnik V (Russia), CoronaVac (China), AZD1222 (United Kingdom), BNT162b2 (Germany), and mRNA-1273(United States of America). We bring forth the certain potential factors that are required when creating vaccines as well as a comparative analysis of data obtained from SARS-CoV-2 vaccine trials for different vaccines as well as environmental impacts of its preparation.
\end{abstract}

\section{Introduction}

A severe concern has become the rapid spread of coronavirus disease throughout the world [1]. The advancement of a powerful antibody against the virus was requested due to the quickly spreading contamination as well as the rising number of deaths of human life. Many Antibodies had effectively entered clinical trials like vector antibodies including nucleic acids-based antibodies \& inactivated antibodies. Numerous research companies, as well as specialists all over the world, had begun attempts for the preparation of successful antibodies so that could give durable as well as quick protection against this virus.

In 2019 December in Wuhan which is a city in China, the World Health Organization also known as WHO later proclaimed a pandemic caused by a serious active respiratory condition coronavirus on March 11 in 2020 [2]. Since recently, corona virus-related mortality has been increasing in a vast percentage of the world. D. Smrž et al guides us that widespread safety precautions, including mandatory mask use, social separation, and handwashing, may have an impact on this illness. Unfortunately, the epidemic would not be over until an effective coronavirus antibody vaccination was produced $[3,4]$. For the past two decades, covid-19 has been the 3rd unique beta-Covid thus far that is extremely contagious but also easily disseminated from one person to another. Covid-19 has recently been diagnosed in $96,981,033$ persons throughout the globe [5]. According

\footnotetext{
*Corresponding author: lalita.chemistry@cumail.in
}

to the WHO [6], the outbreak has resulted in $120,428,199$ reported cases and 2,665,548 fatalities globally as of March 20,2021. This virus has a genome that is identical to RaTG13 with RmYN02 infections discovered in Rhinolophus affinis as well as Rhinolophus malayanus, respectively. It is widely agreed that the virus was transmitted by bats [7]. The diagnostic disease caused by the severe acute respiratory condition is known as Coronavirus (COVID-19), and it can cause gastrointestinal infection, hyper inflammation, cardiovascular pathology, and coagulopathy, as well as cardiac failure. The most common causes of death include co-morbid illnesses such as hypertension, obesity, and diabetes, as well as the patients' weakened immune systems after being infected with the virus [8]. Y. Dong et al provides that different studies have also been undertaken to understand better the illness, as approaches have been established in the hopes of halting the spread of the virus while developing efficient yet safe treatments or vaccinations [9]. Host-cells are infected by the virus by combining ACE2 (angiotensinconverting encym2) receptors for homotrimeric spike (S) viral trans-layer glycoproteins. Once genomics was found, extensive efforts began to create antibodies mostly aimed at the viral spike protein. Various methods were introduced in the human circulatory system for transporting the viral $\mathrm{S}$ protein via antibodies. These vaccinations are accompanied by viral vector antibodies, inactivated virion, fatty nano-molecular mRNA plus DNA methods. Various antibodies were clinically tested but most also discussed the effectiveness as well as 
vaccination immune responses [8]. WHO informed that currently, 56 potential virus antibodies are in clinical testing, while 23 vaccines were authorized/ approved.

\subsection{Overview of Covid-19}

SARS-CoV, MERS-CoV as well as SARS-CoV-1 are the cytoplastic single-strain RNA virus with positive meaning and structural proteins (especially $\mathrm{S}$, envelope including membrane proteins) (containing nucleocapsid) [10]. To proliferate a virus, it must first get into cells in the human body. These receptors are generally employed to control blood flow via capillaries via the enzyme known as ACE2 (angiotensin-conversing enzyme 2) [11]. The $\mathrm{S}$ protein generally plays an important function in generating immunological responses during the progression of the disease [12]. S protein is needed for the virus to access hot cells via virus receptor, angiotensin converting enzyme (ACE2), as well as cell entry [13-15].

The novel coronavirus does have the same receptor but is still stronger. It uses a spike or ' $\mathrm{S}$ ' protein that attaches on its whole surface utilizing one of its four primary structural proteins [11] Two subunits S1 as well as S2 that mediate binding of the receptor for membrane fusion respectively are present in the trimeric $\mathrm{S}$ protein. The $\mathrm{S} 1$ subunit contains a region termed the RBD, which can bind ACE $2[16,17]$. The connection of the $\mathrm{S}$ protein to the ACE 2 receptor leads to intricate conformation modifications and pushes the $\mathrm{S}$ protein to the form of a post-fusion configuration. A possible method for the host immune response to the virus was proposed to decorate the posflusion conformation with N-linked glycans [18]. Past investigations have shown that SARS-CoV $\mathrm{S}$ protein vaccines generate robust cell as well as humoral immunological response in animals including clinical investigations of mouse challenges [19-21]. Likewise, the $\mathrm{S}$ gene is considered a crucial objective for vaccines [22]. The coronavirus $\mathrm{S}$ protein, in particular RBD, could trigger neutralizing antibodies (NAbs) including immune response to the $\mathrm{T}$ cell [23-26]. The RBDspecific igG of coronavirus representing half the $\mathrm{S}$ protein response was found in an experimental examination [27]. Specific RBD plus T cells have also been discovered in patients afflicted [28]. Furthermore, NAb's titers are significantly related to anti-RBD IgG levels, whereas RBD's specific IgG's titers are supposed to replace neutralizing $[26,28]$.

B. D. Quinlan et al provided that in addition, the RBD immunization has been effective initially when NAbs have been produced in mice sans antibody-dependent enhancement mediation [29]. The RBD may be directed as a future-oriented viral target by the earliest RBDbased vaccine development for both SARS-CoV as well as MERS-CoV. Other proteins, aside from $\mathrm{S}$ protein, may also act as antibodies as well as $\mathrm{N}$ proteins, $\mathrm{M}$ proteins, non-structural proteins (nsps), including supplementary proteins. However, the disparity of IFN-I with IFN-III host, including higher pro-inflammatory cytokine, has been linked to both viral protein and its links to host element $[30,31]$.

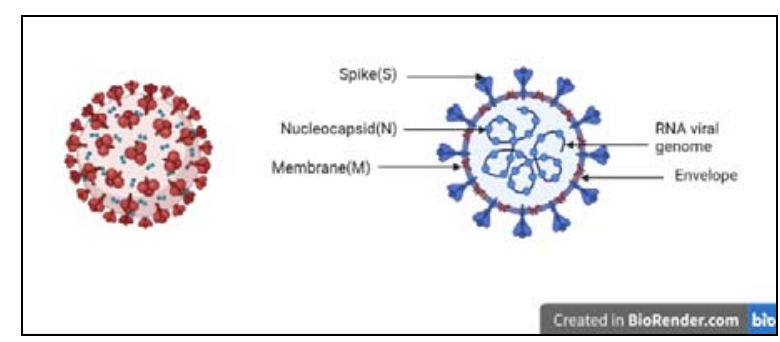

Fig.1. Coronavirus

\subsection{Various coronavirus found in humans}

The various types of corona virus and their illness found in human body are SARS-CoV-2(Covid-19, SARS-CoV (severe acute respiratory syndrome), MERS-CoV (Middle East respiratory syndrome and HCoV-NL63, HCoV-229E, HCoV-OC43, HKU1(minor respiratory symptoms). "Nobody has any immunity to this virus, as its infection is new. This indicates that a very huge proportion of people may be infected. Although the amount of really serious instances is a very low proportion, many persons with acute sickness have a tiny proportion of a very big number. All seven human viruses are known to have been transferred from other animals to people. The virus has been present in animals for years but it was exceedingly unusual highly extreme in people. It was likely bats that caused MERS, SARS, as well as COVID-19. As a temporary host in UK-based research \& innovation, it may be possible for another animal species like the pangoline, to transfer the new Coronavirus from its original host species to people [32].

\subsection{Difficulties in vaccine production}

Hamsters get SARS infection lung alterations but do not seem to get ill. Lung diseases with SARS coronavirus are developing by ferrets and various monkey species but not continuously [33]. W. Liu et al stated that there are difficulties in generating both protective immune system as well as proof for testing SARS vaccination in animal models, that if the protection from infection was insufficient, the improper immune response might produce possible adverse effects. So various vaccinations generated antibodies against spike protein in testing for early SARS in ferrets and singes, but only partially protected them against lung illness [32]. Some lung inflammation vaccinations were also related to subsequent immunization of the virus by mice [34]. These examples provide some understanding of the problems with vaccine production. They demonstrate the importance of stimulating the correct immunological responses, as well as why safety testing is essential.

\section{Types of vaccine}

United Kingdom studies \& data indicated that "the human immune response is extremely carefully tuned. First, viruses or other pathogenic agents must be identified and killed. The body's healthy tissues must not be damaged by an over-active immune reaction. The 
immunological concept has changed in order to combat that protect against a wide range of illnesses." For instance, lymphocytes, called assist $\mathrm{T}$ cells, exist in several kinds that aid with immune responses. The first, Th1, kills cell-infectant bacteria but also viruses. The second regulates larger parasites such as helminths (Th2) (worms). Enabling the incorrect course might raise inflammation but also make the condition worse.

Bukreyev, Alexander et al. reported that lymphocytes and other cells create immune signaling substances known as cytokines as part of normal immunological responses. This coordination increases immunological reactions. Therefore, if these responses are awful, inflames may lead to the closure of important organs, such as the pulse, heart, and kidneys, in extreme situations. In the instance of this virus, several late consequences of the disease may be attributable to this. A very tiny fraction of the patients can contribute to considerably longer coronavirus by an excessive immune reaction. Although, it is yet unknown but also an essential field for research. Vaccines against Coronavirus are therefore needed to generate the proper balance of immune response and safeguard against infection. Therefore, extensive clinical studies will be essential to guarantee that new vaccinations are highly safe and effective [35]. The design of vaccination has three key methods. They differ whether they utilize a complete virus or a bacterium, simply portions of the germ that stimulates the immune system or only genes for certain proteins, not for the full virus [36].

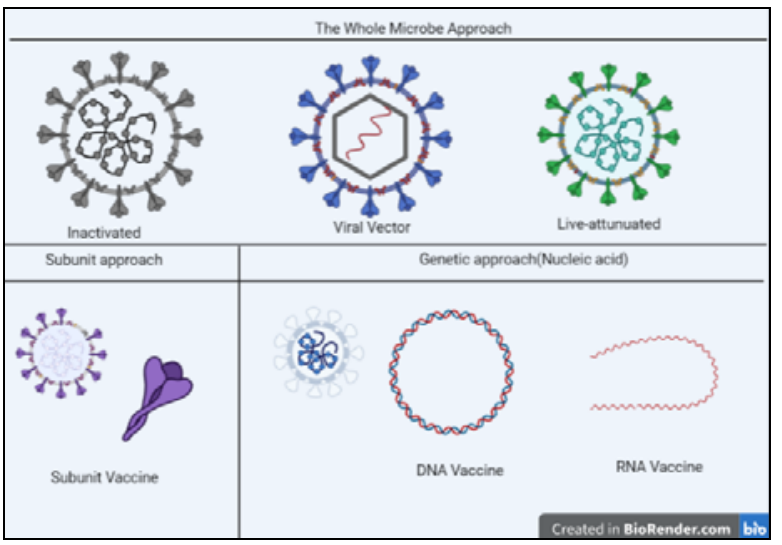

Fig.2. Types of vaccine

\subsection{The whole microbe}

\subsubsection{Inactivated}

Inactivated vaccinations work by exposing a virus that has lost its ability to cause illness. The virus is grown in cell lines, which serve as a medium for the synthesis of enormous amounts of antibodies. Before vaccine inactivation, virus replication is usually preceded by purification as well as concentration [37]. To inactivate the virus, formaldehyde plus beta-propiolactone is utilized in most approved human antivirus vaccinations [38]. Inactivated vaccines need many doses or adjuvants to obtain adequate effectiveness [39]. Examples are Sinopharm (BBIBP), CoronaVac, Covaxin, Sinopharm (WIBP), and CoviVac.

\subsubsection{Viral Vector}

Genetically manipulating the coronavirus gene transportation virus vector and slowly multiplying in infected cells, VV vaccine is produced. Multiplication results in coronavirus synthesis of a protein with subsequent activation of the immune system. Such viral vectors are being designed to be reproducing or nonreproducing [40]. The host's innate immunity may well have a major impact on VBV effectiveness. Non-human or unusual serotype vectors are used to circumvent this $[41,42]$. Examples are Sputnik V, Oxford-AstraZeneca, Johnson \& Johnson as well as Convidecia.

\subsubsection{Live-attenuated}

P.D. Minor indicates that live attenuated vaccinations are successful in the treatment of illnesses like smallpox as well as poliomyelitis [43]. The antibody is being assessed in a preclinical manner and 3 live-attended SARS-COV-2 vaccines use a weakened virus. These vaccinations can, nonetheless, in rare situations return to virulence. Whilst the use of this vaccine is possible, there have been worries about the presence of epitopes that will not cause NOBs or safeguard the immune response being slowed down [44].

\subsection{Subunit Vaccines}

Subunit vaccines are made up of purified antibodies rather than complete microbes, thus various carriers act as a transporter for these kinds of antibodies. The antibodies of anti-SARS-CoV-2 subunit vaccinations are infectious proteins, peptides, as well as nanoparticles. Since subunit vaccinations are generally low in efficacy, adjuvants are necessary to elicit a greater immune system reaction [45]. However, such vaccination methods are quite effective. Antibody delivery systems are the most often utilized technique for obtaining highly expressed recombinant proteins. Therefore, for antibodies that need post-translational alteration, mammalian or insect cells could be used [46]. Bacteria, insects, or cell-based expression systems can also be used as recombinant technologies to produce virus-like particles (VLPs). Anti-coronavirus vaccination built on VLPs is now being evaluated in I/II phase clinical studies. Examples are EpiVacCorona, RBD-Dimer.

\subsection{The genetic approach (nucleic acid vaccine)}

\subsubsection{DNA}

Vaccines transmit the genes of the Coronavirus to living organisms. The concept of immunization is founded upon the translocation of DNA into the cell nucleus, which is coupled by analysis and antigen transcription. 
Plasmids are often used as vectors in DNA vaccinations. The route of delivery of myocytes and keratinocytes has been considered (intramuscular, intradermal, as well as subcutaneous). DNA translocation to the cell nucleus where there is an initiation of antigen production but also interpretation depends on the presuppositions of vaccination. In DNA vaccines, plasmids are frequently utilized as vectors. The route of delivery of myocytes and keratinocytes has been considered (intramuscular, intradermal, as well as subcutaneous). Nevertheless, at the site of injection, DNA vaccines can potentially efficiently implant anticoagulant cells. To elicit a strong immunological response, several delivery mechanisms are utilized $[47,48]$.

\subsection{2 $m R N A$}

J. Ross provides that mRNA vaccines had originally been explored in the 1990s, but their usage was limited due to their inconsistency [49]. Because mRNA contains the genetic data needed to make an antibody, RNA vaccinations, therefore, result in the creation of coronavirus proteins in vivo. An interaction between some of the DNA plasmid patterns and the recombinant RNA polymerase in vitro is established to produce an RNA vaccine. In order to achieve a stable RNA sequence, a synthetic cap analog and a poly(A) tail are added. In order to achieve a stable RNA sequence, a synthetic cap analog and a poly(A) tail are added. Several transport systems (including, cationic peptides, nano-emulsions, as well as lipid nanoparticles) other techniques permitting easier transmission (electroporation but also gene gun) are used to better stabilize the cells [50]. Examples are Pfizer-BioNTech, Moderna.

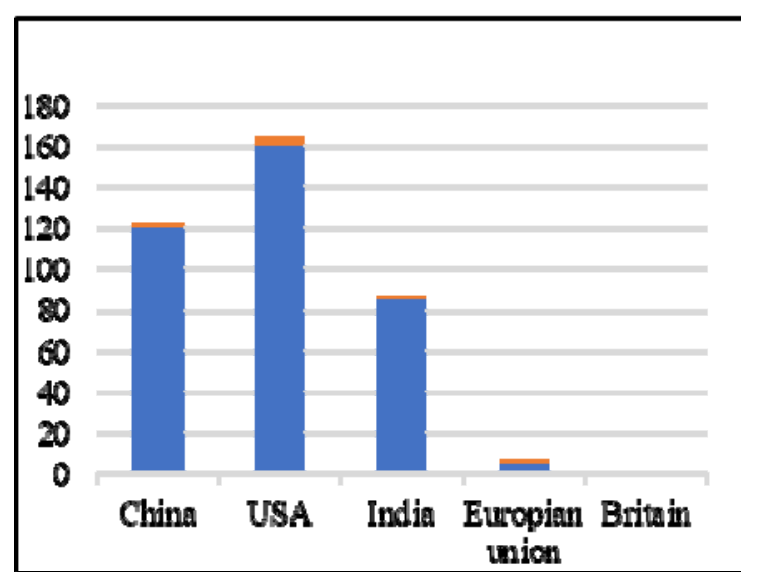

Fig.3. Covid Vaccine produced by top 5 countries/regions, in a million doses as of May 2021.

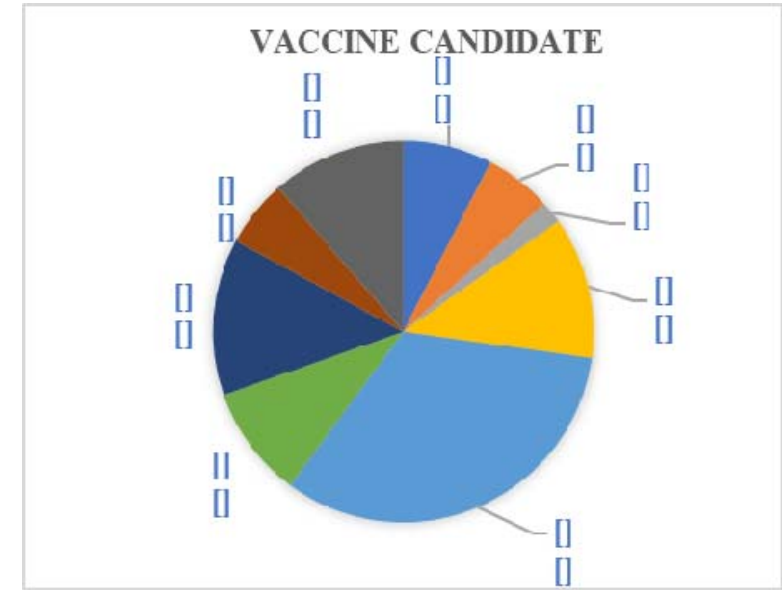

Fig.3. Diagram depicting the many types of study SARS-CoV2 vaccines as of May 2021.

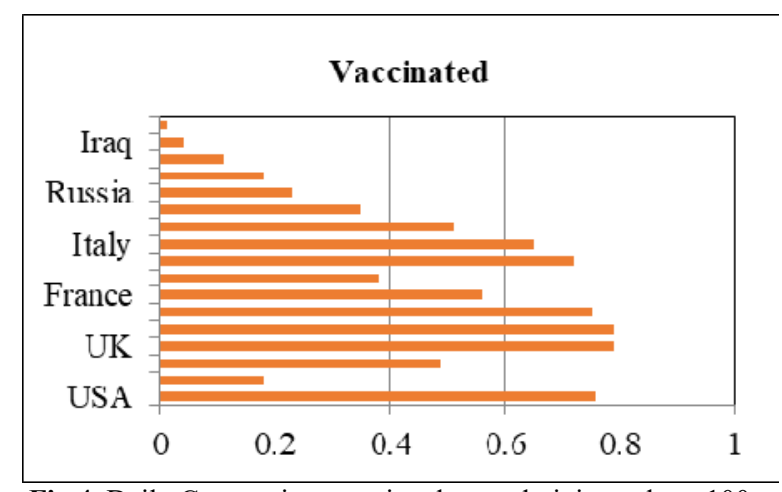

Fig.4. Daily Coronavirus vaccine doses administered per 100 people, Apr 30, 2021.

\section{Impact of new variants on the COVID- 19 vaccine}

Information is continuously collected then assessed on new coronaviral variants. WHO collaborates with academics, health officers with scientists to investigate how different varieties alter the behavior of the virus, particularly their impact on vaccination efficacy. As we understand further, we must do our utmost to limit the viral spread to prevent changes that can impair the efficiency of current vaccinations. Furthermore, producers \& vaccination programs might have to adapt to the growth of the coronavirus: for instance, vaccines could need to integrate more than one strain while developing. Tests should also be established and sustained to evaluate but are of sufficient scale enough diversity to permit a clear evaluation of the results. The findings should be evaluated and evaluated. To understand their effects, the impact studies of vaccinations deployed are equally crucial. It remains vital to stop the spread at the source. The amount of viral transmission but also consequently reduction in viral mutation continue to counteract growing variations [69].

\section{Environmental impact of vaccine production}


Vaccine manufacture, transport plus trash disposal use resources also cause contamination of the environment. The creation of a vaccine is a very effective output of biotechnology. The energy consumption is little, which makes it possible to considerably minimize waste, while the resources themselves are insignificantly utilized. Ecological immunization concerns primarily address two facets: liquid waste treatment (waste liquid) and the destruction of solid waste (producer biomass).

Liquid waste is a culture liquid once it's been separated from the mycelium as removed from the final product. Wasted liquid management is the system of several consecutive units: first suction tank, as well as aeration tank - an air supply, reinforced concrete bottom pool through pipes. Air transcends the total thickness including its fluid, oxygen saturates it, contributing to the intense oxidative process. The use of mycelial waste as part of the nutritional medium for the preliminary treatment of microorganisms with enzymes is a further possible route.

Disposal of solid (and particularly hazardous) wastes. After the mycelium has dried the most rudimentary approach to dispose of is to bring it into urban landfills. Another approach is to lay the mycelium in the earth onto the ground, mixing it with dirt then leaving it for decades (composting is not a cost-effective method). Two potential solid waste disposal routes should be available. One being the sterility of mycelium, which will be supplemented by construction materials for livestock. The next consists of mining different mycelium fractionations, such as lipid, but also using them as detergent rather than inadequate ingredients (wheat oil) or synthetic sprays [70].

All that is needed to keep the vaccinations cool from the enormous freezer to the as well as aircraft need to get the jabs out, to the millions of trash vials plus syringes are potentially problematic. Organizations are using HFC gases to freeze immunizations to very cold temperatures - less than $70^{\circ} \mathrm{C}$ that enable extended distances of storage and delivery [71]. The danger of irresponsible trash disposal that needs education is not known for large numbers of individuals in the public. There are several strategies to tackle this problem: packing, adjusting production, recycling, delivery, manufacturing processes are all extremely promising areas to focus on [72].

\section{Conclusion}

Vaccine Efficacy - The vaccine made from mRNA technology was a definite victor of effectiveness in the 95 percent of overall range with ages accompanied by an efficiency basis of a Protein Subunit of less than 90percent of the total in the United Kingdom. On the currently available variable data, the inactivated viral platform is the lowest.

Dose regimen - In the different platforms studied in this study, 2 vaccines that are CanSino with Janssen (also known as Johnson \& Johnson) of the 12 vaccinations had a 2 dose system.
Reactivity/security - The best pick of all is actually the inactivated virus framework. Due to some persisting worries over stalled trials with negative outcomes, the viral vector system rates below the other 3 .

Target price/accessibility - mRNA vaccine manufacturing can be reasonably scaled up; however, they are already one of the costliest vaccines; the most inexpensive to create is the VVB vaccine. Vaccines against inactivated viruses are reasonably simple and cost-effective, given the COVAXIN. There is nonetheless some evidence that the prices of vaccines imported from China are relatively high.

Logistics - mRNA vaccinations with a heavy cold chain demand are the least.

The vaccine is generally developed from zero throughout a period of several years, however, we have previously licensed vaccinations for combating coronavirus propagation. This consists of efforts of various states to ensure that it conforms to pandemics. This has been achieved by pre-clinical studies in early Phase 1 strategic risk measures and adaptive test designs.

I would like to thanks and show my gratitude towards Dr. Lalita Chopra and respected HOD Dr. Renu for their guidance and support throughout the process of writing this paper. I was grateful for the help of my friends and family without whom I wouldn't be able to complete this paper in a given time.

\section{References}

1. S. Weston and M. B. Frieman, COVID-19: Knowns, Unknowns, and Questions, mSpher 5, no. 2(2020).

2. J. Hiscott et al., The global impact of the coronavirus pandemic, Cytokine and Growth Factor Reviews, 53, pp. 1-9(2020).

3. Z. Střížová, J. Bartůňková, and D. Smrž, "Can wearing face masks in public affect transmission route and viral load in covid-19 Central European Journal of Public Health, 28, no. 2. Czech National Institute of Public Health, pp. 161-162, (2020).

4. S. P. Kaur and V. Gupta, COVID-19 Vaccine: A comprehensive status report, Virus Research, vol. 288. Elsevier B.V., p. 198114 (2020).

5. E. Dong, H. Du, and L. Gardner, An interactive web-based dashboard to track COVID-19 in real time, The Lancet Infectious Diseases 20, no. 5. Lancet Publishing Group, pp. 533-534 (2020).

6. "Weekly epidemiological update - 29 December 2020."

https://www.who.int/publications/m/item/weeklyepidemiological-update---29-december-2020.

7. A. C. Walls et al., Elicitation of Potent Neutralizing Antibody Responses by Designed Protein Nanoparticle Vaccines for SARS-CoV-2, Cell 183, no. 5, pp. 1367-1382.e17 (Nov. 2020).

8. H. Naji, Comparative Analysis of COVID-19 Vaccines, 3, no. 1, pp. 118-120 (2021).

9. Y. Dong, T. Dai, Y. Wei, L. Zhang, M. Zheng, and F. Zhou, A systematic review of SARS-CoV-2 
vaccine candidates, Signal Transduction and Targeted Therapy 5, no. 1 (2020).

10. Y. Chen, Q. Liu, and D. Guo, Emerging coronaviruses: Genome structure, replication, and pathogenesis, Journal of Medical Virology 92, no. 4. John Wiley and Sons Inc., pp. 418-423 (2020).

11. A. Bukreyev et al., Mucosal immunisation of African green monkeys (Cercopithecus aethiops) with an attenuated parainfluenza virus expressing the SARS coronavirus spike protein for the prevention of SARS, Lancet 363, no. 9427, pp. 2122-2127 (2004).

12. K. K. W. To et al., Temporal profiles of viral load in posterior oropharyngeal saliva samples and serum antibody responses during infection by SARS-CoV2: an observational cohort study, The Lancet Infectious Diseases 20, no. 5, pp. 565-574 (2020).

13. M. Hoffmann et al., SARS-CoV-2 Cell Entry Depends on ACE2 and TMPRSS2 and Is Blocked by a Clinically Proven Protease Inhibitor, Cell 181, no. 2, pp. 271-280.e8 (2020).

14. X. Ou et al., Characterization of spike glycoprotein of SARS-CoV-2 on virus entry and its immune crossreactivity with SARS-CoV, Nature Communications 11, no. 1 (2020).

15. P. Zhou et al., Erratum: Addendum: A pneumonia outbreak associated with a new coronavirus of probable bat origin, Nature 588, no. 7836. NLM (Medline), p. E6 (2020).

16. Y. Wan, J. Shang, R. Graham, R. S. Baric, and F. $\mathrm{Li}$, Receptor Recognition by the Novel Coronavirus from Wuhan: An Analysis Based on Decade-Long Structural Studies of SARS Coronavirus, Journal of Virology 94, no. 7 (2020).

17. M. Letko, A. Marzi, and V. Munster, Functional assessment of cell entry and receptor usage for SARS-CoV-2 and other lineage $B$ betacoronaviruses, Nature Microbiology 5, no. 4, pp. 562-569 (2020).

18. Y. Cai et al., Distinct conformational states of SARS-CoV-2 spike protein, Science 369, no. 6511, pp. 1586-1592 (2020).

19. H. Bisht et al., Severe acute respiratory syndrome coronavirus spike protein expressed by attenuated vaccinia virus protectively immunizes mice, Proceedings of the National Academy of Sciences of the United States of America 101, no. 17, pp. 66416646 (2004).

20. Y. ZY et al., A DNA vaccine induces SARS coronavirus neutralization and protective immunity in mice, Nature 428, no. 6982, (2004).

21. M. JE et al., A SARS DNA vaccine induces neutralizing antibody and cellular immune responses in healthy adults in a Phase I clinical trial, Vaccine, vol. 26, no. 50, (2008).

22. F. Amanat and F. Krammer, SARS-CoV-2 Vaccines: Status Report, Immunity 52, no. 4. Cell Press, pp. 583-589 (2020).
23. Y. He, Y. Zhou, P. Siddiqui, and S. Jiang, Inactivated SARS-CoV vaccine elicits high titers of spike protein-specific antibodies that block receptor binding and virus entry, Biochemical and Biophysical Research Communications 325, no. 2, pp. 445-452 (2004).

24. J. Lan et al., Recombinant Receptor Binding Domain Protein Induces Partial Protective Immunity in Rhesus Macaques Against Middle East Respiratory Syndrome Coronavirus Challenge, EBioMedicine 2, no. 10, pp. 1438-1446 (2015).

25. J. Wang et al., The adjuvanticity of an o. volvulusderived rov-ASP-1 protein in mice using sequential vaccinations and in non-human primates, PLoS ONE 7, no. 5 (2012).

26. M. S. Suthar et al., Rapid Generation of Neutralizing Antibody Responses in COVID-19 Patients, Cell Reports Medicine 1, no. 3 (2020).

27. Q. Gao et al., Development of an inactivated vaccine candidate for SARS-CoV-2, Science 369, no. 6499, pp. 77-81, (2020).

28. L. Ni et al., Detection of SARS-CoV-2-Specific Humoral and Cellular Immunity in COVID-19 Convalescent Individuals, Immunity 52, no. 6, pp. 971-977.e3 (2020).

29. B. D. Quinlan et al., The SARS-CoV-2 receptorbinding domain elicits a potent neutralizing response without antibody-dependent enhancement, bioRxiv, p. 2020.04.10.036418 (2020).

30. J. Hadjadj et al., Impaired type I interferon activity and inflammatory responses in severe COVID-19 patients, Science, vol. 369, no. 6504, pp. 718-724 (2020).

31. D. Blanco-Melo et al., Imbalanced Host Response to SARS-CoV-2 Drives Development of COVID-19, Cell, vol. 181, no. 5, pp. 1036-1045.e9 (2020).

32. W. Liu et al., Two-year prospective study of the humoral immune response of patients with severe acute respiratory syndrome, Journal of Infectious Diseases 193, no. 6, pp. 792-795 (2006).

33. L. M. Gretebeck and K. Subbarao, Animal models for SARS and MERS coronaviruses, Current Opinion in Virology 13. Elsevier B.V., pp. 123-129 (2015).

34. C. te Tseng et al., Immunization with SARS coronavirus vaccines leads to pulmonary immunopathology on challenge with the SARS virus, PLoS ONE, vol. 7, no. 4 (2012).

35. A. Bukreyev et al., Mucosal immunisation of African green monkeys (Cercopithecus aethiops) with an attenuated parainfluenza virus expressing the SARS coronavirus spike protein for the prevention of SARS, Lancet 363, no. 9427, pp. 2122-2127 (2004).

36. The different types of COVID-19 vaccines. https://www.who.int/news-room/featurestories/detail/the-race-for-a-covid-19-vaccineexplained 
37. S. Plotkin, History of vaccination, Proceedings of the National Academy of Sciences of the United States of America 111, no. 34. National Academy of Sciences, pp. 12283-12287 (2014)

38. I. Delrue, D. Verzele, A. Madder, and H. J. Nauwynck, Inactivated virus vaccines from chemistry to prophylaxis: merits, risks and challenges.

39. F. Zepp, Principles of vaccine design-Lessons from nature," Vaccine 28, no. SUPPL. 3. Elsevier, pp. C14-C24 (2010).

40. B. Ramezanpour, I. Haan, A. Osterhaus, and E. Claassen, Vector-based genetically modified vaccines: Exploiting Jenner's legacy, Vaccine, vol. 34, no. 50, pp. 6436-6448, Dec. 2016,

41. H. Fausther-Bovendo and G. P. Kobinger, Preexisting immunity against Ad vectors: Humoral, cellular, and innate response, what's important Human Vaccines and Immunotherapeutics 10, no. 10. Landes Bioscience, pp. 2875-2884 (2014)

42. I. R. Humphreys and S. Sebastian, "=Novel viral vectors in infectious diseases, Immunology 153, no. 1. Blackwell Publishing Ltd, pp. 1-9 (2018).

43. P. D. Minor, Live attenuated vaccines: Historical successes and current challenges, Virology 479480. Academic Press Inc., pp. 379-392 (2015).

44. Y. Dong, T. Dai, Y. Wei, L. Zhang, M. Zheng, and F. Zhou, A systematic review of $S A R S-C o V-2$ vaccine candidates, Signal Transduction and Targeted Therapy 5, no. 1. Springer Nature (2020).

45. A. Vartak and S. J. Sucheck, Recent advances in subunit vaccine carriers, Vaccines, 4, no. 2. MDPI AG (2016).

46. I. P. Nascimento and L. C. C. Leite, Recombinant vaccines and the development of new vaccine strategies, Brazilian Journal of Medical and Biological Research 45, no. 12. Associação Brasileira de Divulgação Científica, pp. 1102-1111 (2012).

47. J. J. Donnelly, B. Wahren, and M. A. Liu, $D N A$ Vaccines: Progress and Challenges, The Journal of Immunology 175, no. 2, pp. 633-639 (2005).

48. L. Li and N. Petrovsky, Molecular mechanisms for enhanced DNA vaccine immunogenicity, Expert Review of Vaccines 15, no. 3. Taylor and Francis Ltd, pp. 313-329 (2016).

49. J. Ross, $m R N A$ stability in mammalian cells, Microbiological Reviews 59, no. 3, pp. 423-450 (1995).

50. C. Zhang, G. Maruggi, H. Shan, and J. Li, Advances in $m R N A$ vaccines for infectious diseases, Frontiers in Immunology 10, no. MAR. Frontiers Media S.A., p. 594 (2019).

51. Y. Dong, T. Dai, Y. Wei, L. Zhang, M. Zheng, and F. Zhou, A systematic review of SARS-CoV-2 vaccine candidates, Signal Transduction and Targeted Therapy 5, no. 1. Springer Nature (2020).
52. S. P. Kaur and V. Gupta, COVID-19 Vaccine: $A$ comprehensive status report, Virus Research 288. Elsevier B.V. (2020).

53. Vaxzevria (previously COVID-19 Vaccine AstraZeneca) | European Medicines Agency." https://www.ema.europa.eu/en/medicines/human/EP AR/vaxzevria-previously-covid-19-vaccineastrazeneca

54. Regulatory Decision Summary - Pfizer-BioNTech COVID-19 Vaccine - Health Canada." https://covidvaccine.canada.ca/info/regulatory-decisionsummary-detailTwo.html?linkID=RDS00730

55. I. Jones and P. Roy, Sputnik V COVID-19 vaccine candidate appears safe and effective, The Lancet 397, no. 10275. Elsevier B.V., pp. 642-643 (2021).

56. S. Xia et al., Safety and immunogenicity of an inactivated SARS-CoV-2 vaccine, BBIBP-CorV: a randomised, double-blind, placebo-controlled, phase 1/2 trial, The Lancet Infectious Diseases, vol. 21, no. 1, pp. 39-51 (2021).

57. E. J. Anderson et al., Safety and Immunogenicity of SARS-CoV-2 mRNA-1273 Vaccine in Older Adults, New England Journal of Medicine, vol. 383, no. 25, pp. 2427-2438 (2020).

58. K. E. Stephenson et al., Immunogenicity of the Ad26.COV2.S Vaccine for COVID-19, JAMA Journal of the American Medical Association, vol. 325, no. 15, pp. 1535-1544 (2021).

59. "Clinical Trial of Efficacy and Safety of Sinovac's Adsorbed COVID-19 (Inactivated) Vaccine in Healthcare Professionals - ClinicalTrials.gov." https://clinicaltrials.gov/ct2/show/NCT04456595

60. R. Ella et al., Safety and immunogenicity of an inactivated SARS-CoV-2 vaccine, BBV152: interim results from a double-blind, randomised, multicentre, phase 2 trial, and 3-month follow-up of a double-blind, randomised phase 1 trial, The Lancet Infectious Diseases (2021).

61. "Study to Evaluate Efficacy, Immunogenicity and Safety of the Sputnik-Light - ClinicalTrials.gov." https://clinicaltrials.gov/ct2/show/NCT04741061

62. F. C. Zhu et al., Immunogenicity and safety of a recombinant adenovirus type-5-vectored COVID-19 vaccine in healthy adults aged 18 years or older: a randomised, double-blind, placebo-controlled, phase 2 trial, The Lancet 396, no. 10249, pp. 479488 (2020).

63. A. B. Ryzhikov et al., Immunogenicity and protectivity of the peptide candidate vaccine against SARS-CoV-2, Annals of the Russian academy of medical sciences . 76, no. 1, pp. 5-19 (2021).

64. "A Phase III Clinical Trial to Determine the Safety and Efficacy of ZF2001 for Prevention of COVID19) ClinicalTrials.gov." https://clinicaltrials.gov/ct2/show/NCT04646590\#w rapper 
65. N. al Kaabi et al., Effect of 2 Inactivated SARS-CoV2 Vaccines on Symptomatic COVID-19 Infection in Adults: A Randomized Clinical Trial, JAMA (2021).

66. "Russia approves its third COVID-19 vaccine, CoviVac Reuters." https://www.reuters.com/article/us-healthcoronavirus-russia-vaccine-idUSKBN2AK $07 \mathrm{H}$.

67. "A Study to Evaluate the Efficacy, Safety and Immunogenicity of SARS-CoV-2 Vaccine (Vero Cells), Inactivated in Healthy Adults Aged 18 Years and Older (COVID-19)- ClinicalTrials.gov. https://clinicaltrials.gov/ct2/show/NCT04852705

68. "A Study to Evaluate the Efficacy, Safety and Immunogenicity of SARS-CoV-2 Vaccine (Vero Cells), Inactivated in Healthy Adults Aged 18 Years and Older (COVID-19) - ClinicalTrials.gov." https://clinicaltrials.gov/ct2/show/NCT04852705.

69. "The effects of virus variants on COVID-19 vaccines." https://www.who.int/news-room/featurestories/detail/the-effects-of-virus-variants-on-covid19-vaccines.

70. Klemeš, Jiří Jaromír, et al. "COVID-19 pandemics Stage II-Energy and environmental impacts of vaccination." Renewable and Sustainable Energy Reviews 150 (2021).

71. Intelsius News | The Environmental Impact of COVID-19. https://intelsius.com/news/theenvironmental-impact-of-covid-19/

72. Phadke, Rachana, Ana Carla dos Santos Costa, Kartik Dapke, Shayon Ghosh, Shoaib Ahmad, Christos Tsagkaris, Sunidhi Raiya, M. Subha Maheswari, Mohammad Yasir Essar, and Shahzaib Ahmad. "Eco-friendly vaccination: Tackling an unforeseen adverse effect." The Journal of Climate Change and Health 1 (2021). 
Table 1. Advantages and disadvantages of vaccines [51, 52].

\begin{tabular}{|c|c|c|}
\hline Vaccine type & Advantage & Disadvantage \\
\hline DNA Vaccine & $\begin{array}{l}\text { 1. Improves mood on cell immunological } \\
\text { responses. } \\
\text { 2. It is stable, can be produced, and } \\
\text { collected readily in big amounts. } \\
\text { 3. The synthesized DNA is cold-chain- } \\
\text { free yet stable. } \\
\text { 4. It can be expedited in development. } \\
\text { 5. The management of the infectious viral } \\
\text { particle is not necessary. }\end{array}$ & $\begin{array}{l}\text { 1.Vaccines for human usage remain } \\
\text { unclear for their safety and } \\
\text { effectiveness. } \\
\text { 2. The titers remain modest, yet they } \\
\text { cause cytotoxic as well as humoral } \\
\text { immunity. } \\
\text { 3. Foreign DNA insertion into the } \\
\text { host genome may lead to cell defects. } \\
\text { 4. May cause the creation of } \\
\text { antibodies against itself. }\end{array}$ \\
\hline RNA Vaccine & $\begin{array}{l}\text { 1.Can be created quickly but also offer } \\
\text { low-cost manufacturing possibilities. } \\
\text { 2. Translation of mRNA takes place in } \\
\text { the host cell's cytoplasm, preventing any } \\
\text { chance of host genome integration. }\end{array}$ & $\begin{array}{l}\text { 1.The features of mRNA can affect } \\
\text { the dispersion and dispersion of cells. } \\
\text { 2. It is uncertain, if it is safe or not in } \\
\text { people } \\
\text { 3. Several RNA-based vaccines have } \\
\text { shown safety problems with } \\
\text { reactogenicity. It is equally unstable. }\end{array}$ \\
\hline Subunit Vaccine & $\begin{array}{l}\text { 1.Could prevent viral infection for } \\
\text { vaccinated animals. There is no live viral } \\
\text { particle component. } \\
\text { 2. Therefore, few side effects are safe. }\end{array}$ & $\begin{array}{l}\text { 1.Can have limited effectiveness } \\
\text { potentially imbalance immunological } \\
\text { responses. } \\
\text { 2. Induces a reaction to the } \\
\text { immunological system. } \\
\text { 3. There is a questionable memory for } \\
\text { future answers. }\end{array}$ \\
\hline Vector Vaccine & $\begin{array}{l}\text { 1.Can directly infect APCs which are } \\
\text { stable physically and genetically. } \\
\text { 2. Show a strong immune response to a } \\
\text { very precise gene transfer into your host } \\
\text { cell. } \\
\text { 3. Does not handle infectious particles but } \\
\text { has been widely utilized with favorable } \\
\text { outcomes from the studies for MERS- } \\
\text { CoV. }\end{array}$ & $\begin{array}{l}\text { 1.Could cause the vector to become } \\
\text { pre-immune. } \\
\text { 2. Because of prior exposure, the host } \\
\text { may be immune from the vector, } \\
\text { decreasing its effectiveness. } \\
\text { 3.This viral genome incorporation } \\
\text { into the host genome could result in } \\
\text { malignancy. }\end{array}$ \\
\hline Inactivated vaccines & $\begin{array}{l}\text { 1.Conformation-dependent antigenic } \\
\text { epitopes are easily manufactured and } \\
\text { stably expressed. } \\
\text { 2. In comparison with LAVs, stable and } \\
\text { safer. The technology and infrastructure } \\
\text { necessary for its creation are pre-existing. } \\
\text { 3. Coronavirus and numerous other } \\
\text { illnesses have already been examined. } \\
\text { 4. Together with adjuvants, the product } \\
\text { can be used to boost its vaccination }\end{array}$ & $\begin{array}{l}\text { 1.The antigen that is not significant } \\
\text { might distort the immunological } \\
\text { response. } \\
\text { 2.Need's pathogen growth at } \\
\text { biosafety level } 3 \text {. } \\
\text { 3. To maintain immunity, require } \\
\text { booster injections. } \\
\text { 4. Moreover, it is necessary to handle } \\
\text { huge volumes of viruses and maintain } \\
\text { the integrity of the immunogenic } \\
\text { particles. }\end{array}$ \\
\hline
\end{tabular}




\begin{tabular}{|c|c|c|}
\hline $\begin{array}{c}\text { Live Attenuated Vaccine } \\
\text { (LAV) }\end{array}$ & $\begin{array}{c}\text { 1.It stimulates an innate immune system } \\
\text { TLR } 3 \text { with TLR 7/8 as well as TLR 9 } \\
\text { which includes cells B, CD4 but also } \\
\text { CD8 } \mathrm{t} \text { but is inherent to immunological } \\
\text { activation. }\end{array}$ & $\begin{array}{c}\text { 1.To verify efficacy as well as safety } \\
\text { LAV requires comprehensive } \\
\text { supplementary testing. }\end{array}$ \\
$\begin{array}{c}\text { 2. It could be produced from "cold- } \\
\text { adapted" strains of viruses, reassortants } \\
\text { through genetic reversal. }\end{array}$ & $\begin{array}{c}\text { 2. A nubstitution is possible } \\
\text { results in the development of post- } \\
\text { vaccination recombinants. }\end{array}$ \\
\hline
\end{tabular}

Table 2. Corona Virus Vaccines in Phase III

\begin{tabular}{|c|c|c|c|c|c|}
\hline Vaccine type & Vaccine & Institute & $\begin{array}{l}\text { Interval, } \\
\text { Doses }\end{array}$ & $\begin{array}{c}\text { Temperature } \\
\text { of storage }\end{array}$ & $\begin{array}{l}\text { Origin } \\
\text { nation }\end{array}$ \\
\hline $\begin{array}{l}\text { Adenovirus vector } \\
\text { vaccine }(\mathrm{ChAdOx} 1)\end{array}$ & $\begin{array}{c}\text { Oxford- } \\
\text { AstraZeneca } \\
\text { vaccine (Vaxzevri } \\
\text { a, Covishield) }\end{array}$ & $\begin{array}{c}\text { University of } \\
\text { Oxford, AstraZenec } \\
\text { a, CEPI }\end{array}$ & $\begin{array}{l}1 \text { month to } \\
3 \text { months, } \\
2 \text { doses }\end{array}$ & $\begin{array}{l}2 \text { to } 8^{\circ} \\
\text { Celsius }\end{array}$ & $\begin{array}{c}\text { UK, Sweden } \\
{[53]}\end{array}$ \\
\hline $\begin{array}{c}\text { RNA } \\
\text { vaccine (modRNA i } \\
\text { n lipid } \\
\text { nanoparticles) }\end{array}$ & $\begin{array}{c}\text { Pfizer-BioNTech } \\
\text { vaccine (Comirna } \\
\text { ty) }\end{array}$ & BioNTech, Pfizer & $\begin{array}{l}\text { Half month } \\
\text { to almost a } \\
\text { month, } \\
2 \text { doses }\end{array}$ & $\begin{array}{c}-70 \pm 10^{\circ} \\
\text { Celsius } \\
\text { (ULT) }\end{array}$ & $\begin{array}{c}\text { USA, } \\
\text { Germany } \\
{[54]}\end{array}$ \\
\hline $\begin{array}{l}\text { Adenovirus vector ( } \\
\text { Ad5 recombinant as } \\
\text { well as Ad26 } \\
\text { recombinant) }\end{array}$ & $\begin{array}{l}\text { Sputnik (Gam- } \\
\text { COVID-Vac) }\end{array}$ & $\begin{array}{l}\text { GRIEM (Gamaleya } \\
\text { Research Institute } \\
\text { of Epidemiology } \\
\text { and Microbiology) }\end{array}$ & $\begin{array}{l}\text { Almost a } \\
\text { month, } \\
2 \text { doses }\end{array}$ & $\begin{array}{c}\leq-18^{\circ} \text { Celsius } \\
\quad(\text { freezer })\end{array}$ & Russia [55] \\
\hline $\begin{array}{l}\text { Inactivated (Vero } \\
\text { cells) }\end{array}$ & BBIBP- CorV & $\begin{array}{c}\text { Sinopharm: BIBP } \\
\text { (Beijing Institute of } \\
\text { Biological } \\
\text { Products) }\end{array}$ & $\begin{array}{l}3-4 \text { weeks, } \\
2 \text { doses }\end{array}$ & $\begin{array}{l}2 \text { to } 8^{\circ} \\
\text { Celsius }\end{array}$ & China [56] \\
\hline $\begin{array}{c}\text { RNA } \\
\text { vaccine (modRNA i } \\
\text { n lipid } \\
\text { nanoparticles) } \\
\end{array}$ & $\begin{array}{l}\text { Moderna COVID- } \\
19 \text { vaccine }\end{array}$ & $\begin{array}{l}\text { Moderna, NIAID, B } \\
\text { ARDA, CEPI }\end{array}$ & $\begin{array}{l}1 \text { month, } 2 \\
\text { doses [63] }\end{array}$ & $\begin{array}{c}-20 \pm 5^{\circ} \mathrm{C}[64] \\
\text { (freezer) }\end{array}$ & USA [57] \\
\hline $\begin{array}{l}\text { Adenovirus vector } \\
\text { (recombinant Ad26) }\end{array}$ & $\begin{array}{c}\text { Johnson \& } \\
\text { Johnson }\end{array}$ & $\begin{array}{c}\text { (Johnson \& } \\
\text { Johnson), BIDMC } \\
\text { (Beth Israel } \\
\text { Deaconess Medical } \\
\text { Center), Janssen } \\
\text { Vaccines }\end{array}$ & 1 dose & $\begin{array}{l}2 \text { to } 8^{\circ} \\
\text { Celsius }\end{array}$ & $\begin{array}{c}\text { The } \\
\text { Netherlands, } \\
\text { USA [58] }\end{array}$ \\
\hline $\begin{array}{l}\text { Inactivated Vaccine } \\
\text { (Vero cells) }\end{array}$ & Corona Vac & Sinovac & $\begin{array}{l}2-3 \text { weeks, } \\
2 \text { doses }\end{array}$ & $\begin{array}{l}2 \text { to } 8^{\circ} \\
\text { Celsius }\end{array}$ & China [59] \\
\hline $\begin{array}{l}\text { Inactivated (Vero } \\
\text { cells) }\end{array}$ & $\begin{array}{c}\text { BBV } \\
152 \text { (Covaxin) }\end{array}$ & $\begin{array}{c}\text { Bharat } \\
\text { Biotech, ICMR } \\
\text { (Indian Council of } \\
\text { Medical Research) }\end{array}$ & $\begin{array}{l}1 \text { month, } 2 \\
\text { doses }\end{array}$ & $\begin{array}{l}2 \text { to } 8^{\circ} \\
\text { Celsius }\end{array}$ & India [60] \\
\hline $\begin{array}{c}\text { Adenovirus vector } \\
\text { (AD } 26 \\
\text { recombinant) }\end{array}$ & Sputnik Light & GRIEM & 1 dose & $\begin{array}{l}2 \text { to } 8^{\circ} \\
\text { Celsius }\end{array}$ & Russia [61] \\
\hline $\begin{array}{l}\text { Adenovirus vector } \\
\text { (Ad5 recombinant) }\end{array}$ & $\begin{array}{l}\text { (Convidecia) } \\
\text { Ad5n CoV }\end{array}$ & $\begin{array}{l}\text { CanSino Biologics, } \\
\text { BIBAMMS } \\
\text { (Beijing Institute of } \\
\text { Biotechnology of } \\
\text { the Academy of } \\
\text { Military Medical } \\
\text { Sciences) } \\
\end{array}$ & 1 dose & $\begin{array}{l}2 \text { to } 8^{\circ} \\
\text { Celsius }\end{array}$ & China [62] \\
\hline Subunit & Epi Vac Corona & Vector Institute & 3 weeks, & 2 to $8^{\circ}$ & Russia [63] \\
\hline
\end{tabular}




\begin{tabular}{|c|c|c|c|c|c|}
\hline vaccine (peptide) & & & 2 doses & Celsius & \\
\hline $\begin{array}{c}\text { Subunit } \\
\text { vaccine (recombina } \\
\text { nt) }\end{array}$ & $\begin{array}{c}\text { (RBD-Dimer) ZF } \\
2001\end{array}$ & $\begin{array}{l}\text { (Anhui Zhifei } \\
\text { Longcom } \\
\text { Biopharmaceutical) } \\
\text { AZLBCo. Ltd. }\end{array}$ & $\begin{array}{l}1 \text { month, } \\
3 \text { doses }\end{array}$ & $\begin{array}{l}2 \text { to } 8^{\circ} \\
\text { Celsius }\end{array}$ & China [64] \\
\hline $\begin{array}{l}\text { Inactivated (Vero } \\
\text { cells) }\end{array}$ & WIBP - CorV & $\begin{array}{l}\text { Sinopharm: WIBP } \\
\text { (Wuhan Institute of } \\
\text { Biological } \\
\text { Products) }\end{array}$ & 2 doses & $\begin{array}{l}2 \text { to } 8^{\circ} \\
\text { Celsius }\end{array}$ & China [65] \\
\hline Inactivated & Covi Vac & $\begin{array}{l}\text { TCCRAS (The } \\
\text { Chumakov Centre } \\
\text { at the Russian } \\
\text { Academy of } \\
\text { Sciences) }\end{array}$ & $\begin{array}{l}\text { Half a } \\
\text { month, } 2 \\
\text { doses }\end{array}$ & $\begin{array}{l}2 \text { to } 8^{\circ} \\
\text { Celsius }\end{array}$ & Russia [66] \\
\hline Inactivated & $\begin{array}{l}\text { Qaz Covid- } \\
\text { in (Qaz Vac) }\end{array}$ & $\begin{array}{l}\text { RIBSP (Research } \\
\text { Institute for } \\
\text { Biological Safety } \\
\text { Problems) } \\
\end{array}$ & $\begin{array}{c}3 \text { weeks, } 2 \\
\text { doses }\end{array}$ & $\begin{array}{l}2 \text { to } 8^{\circ} \\
\text { Celsius }\end{array}$ & $\begin{array}{c}\text { Kazakhstan } \\
\text { [67] }\end{array}$ \\
\hline $\begin{array}{c}\text { Inactivated (Vero } \\
\text { cell) }\end{array}$ & Minhai & $\begin{array}{c}\text { (Minhai } \\
\text { Biotechnology Co., } \\
\text { Shenzhen Kangtai } \\
\text { Biological } \\
\text { Products) } \\
\text { MBCSKBP Co. } \\
\text { Ltd. } \\
\end{array}$ & $\begin{array}{l}1 \text { month, } \\
2 \text { doses }\end{array}$ & $\begin{array}{l}2 \text { to } 8^{\circ} \\
\text { Celsius }\end{array}$ & China [68] \\
\hline
\end{tabular}

